DOI https://doi.org/10.18551/rjoas.2017-09.27

\title{
OPENING UP FAMILY SUCCESSION AND BUSINESS CONTINUITY IN INDONESIA: THE CASE OF LOMBOK POST-INDONESIA
}

\author{
Iqbal Mohammad*, Putra Irfan Kharisma, Arifin Zainul \\ Graduate School of Business Administration, Faculty of Administrative Science, \\ University of Brawijaya, Indonesia \\ *Email: iqbal07@ub.ac.id
}

\begin{abstract}
This study employs a business exit concept of a family-owned business and provides a deeper understanding on the success of the business. Furthermore, this study aims to determine the process of family succession prior to the continuity of the business owned by family members. This study is a qualitative study, employing case study design which sources were obtained from the CEO of Lombok Post-Indonesia. The data of this study were obtained through interviews and observation. The results showed that managing FOBs is a complicated and demanding task to do, especially within the event of choosing particular candidate for future succession since not every family member is intrested to engage in family-owned entreprises. Furthermore, FOBs does not always have any objectives to pass on the leadership to the family member unless they are ready and well- prepared with sufficient knowledge to take over the business.
\end{abstract}

\section{KEY WORDS}

Family-owned business, succession, business continuity.

The development global business keeps shifting dramatically. Intense competition and dynamic business environment require companies to be aggressive and competitive. One category of enterprises included in the development of the global business is family-owned businesses (FOB). Substantial challenge in the business environment necessiattes FOBs to become more competitive and agile in planning and implementing their strategies. Almost every global and leading companies at the present time was established from small scale enterprises founded by families. Donnelley (2002) in his article suggests that an organization can be said to be a family-owned business (FOB) and an organization when there are more than two family members who work together and share the same goal.

Several world-class companies which are family-controlled, were able to sustain their strategies and established themselves as 'distinctive' family businesses as written in Fortune Global 500 with 19 percent share. Based on the McKinsey-Bloomberg Company Report, the 'top ten' family-owned business was not merely dominated by the Western economy, but also Asian. In general, every country is characterised by the involvement of family-owned businesses in their economic development. Whilst it is true that these companies are publicly listed, the definition of family business is not yet clear.

As defined in many literature in the domain of entrepreneurship and family business, FOB is defined as an organisation that is managed and owned by family members (HilburtDavis \& Dyer 2003). Whether or not an owner releases the whole or partial portion of the business ownership is not yet determined in the literature of FOB. This is due to the modest and narrow definition of FOB suggested by scholars which made it difficult to state a concise and agreed definition of FOB (Astrachan \& Shanker 2003). Nonetheless, the study of McKinsey-Bloomberg Company report in 2014 has provided the list of large family-founded companies and has made an assumption that a business is still perceived as an FOB if it is indicated by major ownership that founders' hold despite its publicly-listed status. Thus, we would argue that any definition of FOB is applicable to any contextual basis which is relevant to a certain research objectives. 
Ever since its first discussion appeared on prominent academic journals two decades ago, ${ }^{1}$ research on FOB topics have started to grow significantly until present. The discussion on FOBs continues to gain awareness among scholars as well as professional consulting groups due to its uniqueness. Indeed, an FOB is different compared to non family-owned business. The different nature between both types of businesses has been a concern in numerous studies as stated by (Kelly, Athanassiou \& Crittenden 2000). In their article, Kelly et al (2000) explain that family-owned and non-family owned businesses are different due to their different patterns of influence, organizational climate and processes. Furthermore, an FOB is generally more stable yet it has more conservative attitude (Kelly et al 2000; Donkels \& Frohlick 1991). Despite the tendency to dichotomize between family-owned and non-family owned businesses, to some extent an FOB could be more flexible in making speedy decisions, due to the nature that family members controls both: the ownership and management. Thus, FOB appears as a unique phenomena for its characteristics of having both advantages and disadvantages. Moreover, regarding to Kelly et al's (2000) explanation, FOBs are engine ignition of a nation's economy as proven by various evidences related to successful businesses in the world.

Table 1 - List of Large Family-Owned Businesses

\begin{tabular}{|c|c|c|c|}
\hline Company & Country (founded) & Industry & Revenue, 2013, (US\$ bn) \\
\hline Walmart & United States (1962) & Retail & 476.3 \\
\hline Vokswagen & Germany (1937) & Automotive & 261.7 \\
\hline Glencore & Anglo-Swiss (1974) & Commodities & 232.7 \\
\hline Samsung & South Korea (1969) & Electronics & 209 \\
\hline EXOR & Italy (1927) & Finance/Indutrial & 151.1 \\
\hline Ford & United States (1903) & Automotive & 146.9 \\
\hline Lukoil & Russia (1991) & Oil & 141.4 \\
\hline MsKesson & United States (1833) & Pharmaceuticals & 137.6 \\
\hline FoxConn & Taiwan (1974) & Electronics & 109.9 \\
\hline
\end{tabular}

Source: McKinsey—Bloomberg Company Report 2014 (cited in http://economist.com).

In developing economies such as Indonesia, prominent and dominant businesses are being controlled and owned by family groups, similar to any other countries in the Eastern and Southeast Asia (Carney \& Gedajlovic 2003). Moreover, Indonesia has the highest percentage of family business groups among any other country in the Southeastern region (Carney \& Gedajlovic 2003). According to a survey on family businesses conducted by IBFC, FOBs account for more than $60 \%$ of all the listed companies In the Southeast Asian region, where they frequently outperform non-family controlled companies (IBFC 2014). In Indonesia, the existence of FOBs that later held the status as 'conglomerate groups' such as Salim group, Astra Group, Sinar Mas, Lippo Group, Gudang Garam, Djarum as well as several other dominant FOBs in the country were politically supported by the Indonesian government to build the industrial fundamental during the post-war era (Sato 1993; Carney 2005). In fact, Mursitama (2006) highlighted that sales of the top 100 private business groups represent approximately $20 \%$ of Indonesia's gross product for the top 200 private business groups in 1993 that had not only cover a quarter of the Indonesian national economy, but also the size of the business groups that exceeded the size of Indonesian state-owned enterprises (Sato 2003). Thus, FOBs are dominant in the economic development since the post-world war era, whereby business groups established and grown by families are undoubtedly important entities. It is noteworthy that the discussion of FOBs does not merely focus on the survival, growth and the performance of such business, but also to some extent ways in which businesses started to prepare an event of leadership succession.

Business succession is not only regarded as a mechanism to switch ownership, but it can also be regarded as an entrepreneurial recycling process (Mason \& Harrison 2006; DeTienne 2010) whereby founders' of a business to somepoint in their lives must depart from

\footnotetext{
${ }^{1}$ Dyer and Handler's (1994) exploration the connection between families and entrepreneurial dynamics; Brockhaus's historical view of entrepreneurship and the future for family business' research (Entrepeneurship: Theory \& Practice, 1994).
} 
the firm they have created and pass the torch of leadership to their inheritors as an avenue to refresh as well as enhance the sustainability of the FOB. In the context of FOBs, Nordqvist et al (2013) suggest that succession should be seen as a complex process which is influenced by personal goals of owners, family structure, ability and ambitions of potential successors and legal and financial issues. Furthermore, survival is underlined as a critical component in the post-stage of successions. Whereas, it is indicated that only $30 \%$ of FOBs have survived the transition between generations in the second generation, while only $12 \%$ were able to survive the third generation and only $3 \%$ were able to develop to the fourth generation (Hall et al 2001). Hence, it neccessitates an attention to the process of succession in FOBs as well as critical aspects that drives the continuity of the business once successors' undertake the management control and the ownership (Collins et al 2016). It has been mentioned in previous studies that succession is a cumbersome issue to cope with. In fact, many FOBs could not survive once the second generation have taken the torch of leadership. As an evidence in the Indonesian context, an FOB inherited by Rahman Tamin failed to keep developing due to conflict of interests that occurred among family members (Panglaykim, 1984). It triggers a question: why do FOBs often face difficulties that results in the discontinuance of the FOB? Is it merely due to the management issues, conflicts between family members or are there any dilematic issues that the founder failed to solve during the succession process?

Based on those questions, researchers aim to highlight some relevant aspects (1) the importance of managerial roles that involves the family; (2) Family dynamics prior to select an incumbent's successor; and, (3) the design of the firm founder-successor relationship within the management of FOBs. The researchers specofied the focus of thi study to Lombok-Post, a media company under the management of Jawa Pos News Network (JPNN)-Indonesia. Presently, JPNN is the largest newspaper network in Indonesia with 171 print media companies, established mostly via mergers and acquisitions with local newspapers across the country (Nugroho, Putri \& Laksmi 2012). In Indonesia, media companies started to expand dramatically in the aftermath of the Indonesia's political reform in 1998. The acceleration of this industry has reached to the point where conglomerates controls most of media channels in Indonesia (Nugroho et al 2013). Moreover, highlighting the facts of Indonesian newspaper industry, contradictory finding have indicated that despite the profit that increases overtime for newspaper key players (such as: Kompas and Jawa Pos) the industry is starting to get left behind, not literally dead, but it is on a life support (Nugroho et al 2013). The Indonesian media industries are mostly privatey-owned (family groups), hence, their sustainability are at the crossroads, especially for conventionally operated printed media. Thus, companies of any business field, hold the urgency to ensure the continuity of their businesses. For FOBs, ensuring the continuity of the business also means extending the family values generating traditions (Salvato, Chirico, Sharma 2010). On the other hand, losing the business will contribute to the loss of socioemotional wealth, family identity, ability to strengthen the family's influence as well as the continuation of the family dynasty (Gómez-Mejía et al 2007; DeTienne, McKelvie \& Chandler 2015). Hence, exploring family succession in the media industry in Indonesia is necessary, not only due to the uniqueness of the FOBs characteristics, but also the domination of media industry within nations' economy and costs associated that cause businesses fail to sustain.

\section{LITERATURE REVIEW}

Closer Look on Family Owned Business (FOB). Since the discussion of the FOB phenomenon is quite extensive as it intersects with multiple disciplines, different contexts, as well as different unit levels of analysis being employed, we need to emphasize more on the process and the arts of managing dynamics and paradox rather than solely focusing on the success or failures, although success and failures often can be associated with how FOBs progress with their entrepreneurial continuum. In an attempt to consolidate the literature of FOBs, Sharma (2004) reviewed 217 scholarly written articles following her (Sharma 2004) review of the previous work by Sharma, Chrisman and Chua $(1997,1998)$. Further, Sharma 
(2004) noted that regardless of the attempted objective to provide an overview of the FOB literature and the scope of the study, previous argument made by Sharma et al $(1997,1998)$ lacked of detail prescriptions of individual studies and comprehensive listing of the scholarly work published. Hence, Sharma (2004) has provided a much clearer assessment on the FOB literature by providing fruitful insights on: (a) the domain of the field; (b) the level of the analysis of the study; and, (c) the strategies employed to obtain knowledge and dissemination. An FOB prepares itself on the basis of family and business even though both are distinct institutions which have different purposes and values even if they are regarded a unity in the family company (DeTienne \& Chirico 2013). The main functions of family are related to the family care and education of members, while the function of a business is related to the production and distribution of goods and services (DeTienne 2010).

Defining the FOB from a strategic management viewpoint, Sharma et al (1997) define FOB as "a business governed and/or managed on a sustainable, potentially crossgenerational, basis to shape and perhaps pursue the formal or implicit vision of the business held by members of the same family or a small number of families" (p.2). Furthermore, these authors (Sharma et al 1997) contend that in the context of strategic management, FOBs are assumed to have threshold of goals to pursue, a strategy to accomplish certain goals, and mechanisms to implement the strategy and control the firm's progress toward the achievement of its goals. The work done by Sharma (2004) over than a decade ago had strengthened up our understanding on FOBs holistically, rather than solely focusing on the distinction between a family and a non-family ones. Indeed, the involvement of the founder's family in the ownership, governance and management has formed characteristics of family businesses different from the non-family ones (Klein, Astrachan, \& Smyrnios, 2005; Astrachan 2010). Nonetheless, FOBs are stereotypically known for conservative planning and organic expansion that might narrow their growth compared to non-FOBs (Astrachan 2010).

In a previous study, Choi, Zahra, Yoshikawa and Han (2015) noted that research on FOB have indicated that family owners who control a firm's management are prominent in the developed countries and developing countries where the corporate control by markets is weak. Moreover, FOBs tend to assign family members as CEOs or holding other top tier managerial positions as the consequence of non-financial motives such as a need for belonging, preserving family wealth, nurturing the social status and maintaining family traditions (Gómez-Mejía et al., 2007; Zellweger \& Astrachan, 2008; Salvato et al 2010; Choi et al 2015). FOB's are often exposed to failure, mainly caused by the inability to establish professional leadership. A previous study done by Stewart and Hitt (2012) has highlighted some important caveats on why FOBs often fail to professionalize (Yildirim-Öktem \& Üsdiken 2010) as well as the possibility of principal conflicts occurred in private FOBs.

The Continuity of FOB's. Continuity of FOBs is a conflicting issue that may trigger anxious feelings among the founders' of the firm. This is due to strong emotional attached to the firm, anxiety of loosing accumulated and socioemotional wealth (DeTienne et al 2015). It needs a lot of commitment for family members to ensure the continuity of the FOB. According to Salvato et al (2010), commitment is a psychological state that forces an individual to conduct a particular action of relevance. FOBs are by far committed-intensive entities as family members are emotionally attached to the business (Salvato et al 2010). Commitment to grow and sustain FOBs is often being associated with the family member's responsibility in maintaining not only the performance but also the ownership structure of the firm. Nonetheless, planning and nurturing the FOB's continuity do not occur without challenges. In an article, Ward (1997) has identified that there are at least six crucial challenges that threat the continuity of FOBs: (1) Maturing business life cycles and increasing competition; (2) Limited capital to fund both family needs and business growth needs; (3) Weak next-generation business leadership; (4) Inflexibility and resistance of the Entrepreneurial leaders to change; (5) Conflicts among sibling successors; and, (6) Disparate family goals, values, and needs (p.325). Thus, success and continuity of FOBs are followed by various problems. To overcome these confronting issues, FOBs must design some strategies in mind and strategic actions to sustain. The notion that FOBs must 
formulate, implement and control strategies to achieve particular goals had sometimes turned out to neglect the strategic importance itself, since family interests and values are incorporated into the goals and objectives arranged for the firm (Sharma et al 1997).

Business Succession: A Founder's Choice. While it is true that FOBs engage themselves in family ties, emotional and psychological wellbeing of the family to the firm, in a certain moment, a founder will sooner or later leave the business (DeTienne 2010). Business succession is very crucial in maintaining the continuity of the family enterprise and thus, taking a leave is a strategic mechanism to ensure the continuity of the firm. Furthermore, founder's centrality is believed to have an impact on firm's strategy and decision making (Sharma et al 1997) which includes founder's role in selecting future successor as well as identifiying the potency for the entrepreneur to be engaged after leaving as a trusted family member, advisor, board member, or finance caretaker (Neubauer, 2003). Hence, Sharma et al (1997) contend that an organization can be characterized as authoritarian, centralized, lacking in trust, delegation and planning, impulsive; and, highly dependent on power due to the firm's centrality or closeness to the founder. Nonetheless, dependencies of FOBs on their founders especially when emotions are attached could be a possible threat to the continuity of the firm unless the firm attempts to overcome it by performing a strategic approach as part of their value. The strategic approach that an FOB possesses depends on its ability to preceed succession planning as part of it.

Succession Planning is the most vulnerabe part that causes failures in family firms due to some problems that are often faced by family firms, should they fail to execute. Sudden retirement of a founder/CEO's firm (e.g. illness, death) will disrupt the firm massively (Sharma et al 2003), especially when there is no safeguard mechanism such as succession planning being prepared prior to the founder's leave. Thus, preparing succession plan in mind is an avenue to mitigate unprecedented disruption. Regardless of that, planning for a respected founder's leave is never an easy process, particularly if he/she is somewhat resistant, resulting in an avoided and postponed succession process (Liu, Eubanks \& Chater 2015). Moreover, as mentioned by Liu et al (2015), founder's choice to involve family member will be more likely result in a smoother transition to a new CEO. This is due to the fact that involving family member to takeover the firm would in some ways seem "easier" because of the familiarity with the business and being regarded as a "trusted entity" to the CEO and key stakeholders (Liu et al 2015).

\section{METHODS OF RESEARCH}

This research employed a qualitative research method (Miles, Hubermen \& Saldana 2013) since the researchers attempted at describing the phenomena of the succession of family-owned business related to the sustainability of the business. In examining the business exit happended to Jawa Pos News Network and Lombok post, the researchers focused on gaining perspectives by administering in-depth interviews with the CEO/Owner of Lombok Post and the successors. In their article on family business, De Massis and Kotlar (2014) noted, "family business is a heterogeneous field that encompasses multiple theoretical approaches and levels of analysis, and we believe that diversity can and should be reflected in the way in which case studies are used" (p.15). Case study is particularly helpful in understanding the process deployed in family firms, an area which is often being neglected (De Massis \& Kotlar 2014). Hence, following the guideline proposed by De Massis and Kotar (2014), we investigated the necessity to conduct this research under the case study design, particularly in exploring features and dimensions that determine family firms' behaviours and processes within the context of family succession.

\section{RESULTS AND DISCUSSION}

Founder's-Successor's Perspective on Family Succession. The founder and successors' perspectives on their experience in conducting the transition are found to be relevant and fruitful to the understanding of the family succession at Lombok Post. Founder's 
response as presented in Table 4.1 gives an interesting view that initially the founder had no intention to inherit the business the his son. Nonetheless, realizing the necessity to bring succession comes in mind when the founder was anxious about the future of the firm due to his limited capacity in running the business in the future. Possible reasons to explain why anxiety arises are: (1) physical state of the founder due to aging condition; (2) limited capability to overcome environment dynamics and uncertainty compared to the younger gnenerations; and, (3) maintaning the business as part of the family value. Moreover, AY as the successor felt that it is necessary for FOBs to pass on the business to the family members regardless of the changing nature, objectives and directions of the firm in the future whether or not to inherit the firm to the third generation.

It has been the nature that often a founder realizes the necessity to pass on the firm to his/her inheritors not only by means of maintaining the kinship and the accumulated wealth, but also, as a learning process for his/her inheritors. Moreover, trustworthiness to family members are often distinct compared to non-family members at the firm, although, there are still possibilities to prepare a succesion for non-family members who are capable of running the firm in the future. Failure of a succession does not only leave a firm in jeopardy, but it also leaves the founder's family less option in sustaining and continuing the entrepreneurial journey of the family and its tradition. Thus, we found that for both: founder and successor clearly need a succession for a continued success of the firm and familiness.

Tabel 2 - Respondents' Perspectives on Family Succession

\begin{tabular}{|c|c|}
\hline $\begin{array}{c}\text { Key } \\
\text { Informant }\end{array}$ & Responses \\
\hline \multirow{3}{*}{ IH 1} & $\begin{array}{l}\text { "It has never been my intention and obsession to pass on the business to my children, but as I age } \\
\text { and find myself becomes limited in terms of my capacity and capability as well as the fact that the } \\
\text { dynamics have changed, it is a good option. Not all capabilities possessed in the past will be able to } \\
\text { be utilized, and I think passing on my business to my family becomes an important objective at the } \\
\text { end" }\end{array}$ \\
\hline & $\begin{array}{l}\text { "In my opinion, the second generation need to take control of the family firm to maintain the business } \\
\text { as a realistic change, without leaving the firm's loyalists and those who have the capacity to sustain } \\
\text { the firm" }\end{array}$ \\
\hline & $\begin{array}{l}\text { "I started the succession process to my son at the age of } 54 \text {. It was not an easy process to convince } \\
\text { him because he had planned to work outside media industry, but as time pass by he started to grow } \\
\text { interests in working in this field" }\end{array}$ \\
\hline AY 1 & $\begin{array}{l}\text { "In my opinion, leadership succession in FOB must be passed on to the next generation especially } \\
\text { family members of the second generation, although, the direction and objectives may change once } \\
\text { the second generation takes over and may or may not be passed on to the third generation" }\end{array}$ \\
\hline
\end{tabular}

Succession Planning at Lombok Post. The second focus of this study was the question of "How do you view succession planning and how was it done in your firm?" Responses from both: the founder $(\mathrm{IH})$ and the successor $(\mathrm{AY})$ were consistent. IH mentioned, related to his experience of succession, he summarized that what had been undertaken in his firm was both: planned and unplanned. It was unplanned since the founder had no intention at the beginning to leave his firm. Some aspects may be able to explain why the succession was unplanned: (1) no interests of the future successor to run the firm, especially when the founder still holds full control and forces family members to continue the business; or, (2) future successors decline to take the throne due to their different carreer orientation.

The planning of succession sometimes becomes problematic for firm founders. Socioemotional aspect is often the case, particularly during the process of choosing a suitable candidates. IH as a founder had planned the succession for a long period of time and had been willing to relinquish his tittle and select the eldest member of the family to take over the firm. IH eventually gave his position to his heir considering the educational background of his successor which is relevant to the business. The succession process is a planned action regarding to the fact that the successor was sent to obtain formal education related to the field. AY as a successor was sent to boarding school and university in order to obtain formal education related to human capital development. Moreover, AY was willing to take over the leadership, not only because the firm is a FOB, but he also had the confidence 
to run the firm since he already obtained adequate skill related to the field. As the founder, IH had chosen his eldest son instead of his other children because the other heirs had low interests in the firm. In fact, the other chidren preferred establishing their career as accounting consultants; eventhough later on they were hired as the treasurer of the firm and strategic business manager of Lombok TV.

Another fact that is revealed from the interview is the fact that Lombok Post had not prescribed any certain criteria in determining the successor, as there was only one strong candidate. IH only had $\mathrm{AY}$ in mind due to the fact that his sisters chose different career path, even though they eventually joined the firm. Thus, it becomes an interesting insight as AY was chosen not only because he was well-educated and had adequate experience, but also because he is the eldest child in the family. In the cultural context, hierarchy and gender are important aspects to consider. Eldest sons usually have a greater responsibility since they are regarded as the representation of the father as a leader of the family.

Table 3 - Interview Responses on the Succession Planning

\begin{tabular}{|c|l|}
\hline $\begin{array}{c}\text { Key } \\
\text { Informant }\end{array}$ & \multicolumn{1}{c|}{ Response } \\
\hline \multirow{5}{*}{ IH 2} & $\begin{array}{l}\text { "Basically, the succession process that I undertook was both: planned and unplanned. I never } \\
\text { planned the succession before because I gave my children the freedom of their own whether or not } \\
\text { to continue the business. The fact that my son is interested to take over (the firm), I started thinking } \\
\text { to prepare him for the leadership succession. I needed to have control on the succession plan for } \\
\text { the continuity of the business and to minimize risks" } \\
\text { "I have chosen my eldest child because the others had chosen different career paths outside this } \\
\text { business" }\end{array}$ \\
\hline \multirow{5}{*}{ AY 2 } & $\begin{array}{l}\text { "Succession can be well prepared if we are able to predict the business' future, it would be different } \\
\text { if it happens to the first generation (founder). The family succession in my opinion is particularly } \\
\text { necessary for the third generation because usually the third generation are inherited with luxuries } \\
\text { and privileged with a well established firm, unlike the second generation who experiences the } \\
\text { struggle of his/her parents when working with the business" }\end{array}$ \\
\cline { 2 - 3 } & $\begin{array}{l}\text { "The succession plan was quite challenging because my father prepared the process from the basic } \\
\text { step: education in which he sent me to attend a boarding school and University majoring } \\
\text { Communication" }\end{array}$ \\
\cline { 2 - 3 } & $\begin{array}{l}\text { "When I joined the firm, I did not have the luxury to be directly employed in a strategic position, } \\
\text { rather I was hired as a journalist and I was involved in various roles and duties. I took around five } \\
\text { years of learning before I gained full trust to lead the firm" }\end{array}$ \\
\hline
\end{tabular}

\section{CONCLUSION}

Succession is often problematic due to some non-technical issues and high emotional content during the process. If the succession fails in the management, the succession planning will fail often, which later may cause big failure for the FOB itself. Most people think that if the corporate strategy is properly implemented, everything will go smoothly. Yet, the fact shows different things. If the founder is excellently managing $F O B$, he/she will become irreplaceable. Appropriate management applied in the FOB is not merely about winning the business strategies, but also in the quest of preparing a successor in order to ensure the continuity of the firm.

It is important to note that succession and leadership in FOBs are two crucial elements of how firms' objectives and kinship are able to encounter the dynamic environment. Furthermore, when the owner and the family begin to focus on succession planning, there will be many options and considerations in developing the next generation. Challenges and financial issues usually occur in preparing the next generation to take over the business. Various efforts should be done to help seniors in dealing with emotional and financial challenges that will be experienced by the next stage owner. Aging also one of the reasons of founders' retirement plan until the heirs are ready to take over the firm. Problems usually arise from the owners who often consider next generation too young to make a choice, giving the next generation a dilemmatic choice.

In the context of this study, business succession in an FOB was necessary. Considering the dynamic environment of the industry, succession option should not be taken 
for granted. Owners must consider other alternatives such as positioning the family under the patronages of parents' business partners who serve to support the welfare of the family. More importantly, the values believed in the family help them building a succesfull business. Values and beliefs shared in a firm support the continuity of the business and provide good long-term thoughts related to the firm. This transition model also helps to provide competitive feeling as the successor feel that they are selected due to their leadership capacity and their own achievements.

Some interesting facts about the context of FOB have been found in this study, yet we believe that this study can be extended to involve cultural aspects and family identity as the determinants of the success of business succession. In addition, we believe that the theories of family business that we used in this study suffer from some weaknesses. Since this study is a qualitative research, researchers are unable to generalize the finding of this study to other context. Therefore, we recommend that future researcher explore this issue through other research method conducted to multiple family business companies to obtain more interesting findings.

\section{REFERENCES}

1. Astrachan, J.H. and Shanker, M.C., 2003. Family businesses' contribution to the US economy: A closer look. Family business review, 16(3), pp.211-219.

2. Astrachan, J.H., 2010. Strategy in family business: Toward a multidimensional research agenda. Journal of Family Business Strategy, 1(1), pp.6-14.

3. Carney, M. and Gedajlovic, E., 2003. Strategic innovation and the administrative heritage of East Asian family business groups. Asia Pacific Journal of Management, 20(1), pp.526.

4. Carney, M., 2005. Corporate governance and competitive advantage in family-controlled firms. Entrepreneurship theory and practice, 29(3), pp.249-265.

5. Choi, Y.R., Zahra, S.A., Yoshikawa, T. and Han, B.H., 2015. Family ownership and R\&D investment: The role of growth opportunities and business group membership. Journal of Business Research, 68(5), pp.1053-1061.

6. Collins, L., Grisoni, L., Tucker, J., Seaman, C., Graham, S., Fakoussa, R. and Otten, D., 2016. The modern family business: Relationships, succession and transition. Springer.

7. De Massis, A. and Kotlar, J., 2014. The case study method in family business research: Guidelines for qualitative scholarship. Journal of Family Business Strategy, 5(1), pp.1529.

8. DeTienne, D.R., 2010. Entrepreneurial exit as a critical component of the entrepreneurial process: Theoretical development. Journal of Business Venturing, 25(2), pp.203-215.

9. DeTienne, D.R. and Chirico, F., 2013. Exit strategies in family firms: How socioemotional wealth drives the threshold of performance. Entrepreneurship Theory and Practice, 37(6), pp.1297-1318.

10. DeTienne, D.R., McKelvie, A. and Chandler, G.N., 2015. Making sense of entrepreneurial exit strategies: A typology and test. Journal of Business Venturing, 30(2), pp.255-272.

11. Donckels, R. and Fröhlich, E., 1991. Are family businesses really different? European experiences from STRATOS. Family business review, 4(2), pp.149-160.

12. Donnelley, R.G., 1988. The family business. Family Business Review, 1(4), pp.427-445.

13. Gómez-Mejía, L.R., Haynes, K.T., Núñez-Nickel, M., Jacobson, K.J. and MoyanoFuentes, J., 2007. Socioemotional wealth and business risks in family-controlled firms: Evidence from Spanish olive oil mills. Administrative science quarterly, 52(1), pp.106137.

14. Hall, A., Melin, L. and Nordqvist, M., 2001. Entrepreneurship as radical change in the family business: Exploring the role of cultural patterns. Family Business Review, 14(3), pp.193-208.

15. Hilburt-Davis, J. and Dyer, W.G., 2003. Consulting to family businesses. A practical guide to contracting, assessment, and implementation. San Francisco, CA: J osseyBass/Pfeifler. 
16. Kelly, L.M., Athanassiou, N. and Crittenden, W.F., 2000. Founder centrality and strategic behavior in the family-owned firm. Entrepreneurship Theory and Practice, 25(2), pp.2742.

17. Klein, S.B., Astrachan, J.H. and Smyrnios, K.X., 2005. The F-PEC scale of family influence: Construction, validation, and further implication for theory. Entrepreneurship Theory and Practice, 29(3), pp.321-339.

18. Liu, C., Eubanks, D.L. and Chater, N., 2015. The weakness of strong ties: Sampling bias, social ties, and nepotism in family business succession. The Leadership Quarterly, 26(3), pp.419-435.

19. Mason, C.M. and Harrison, R.T., 2006. After the exit: Acquisitions, entrepreneurial recycling and regional economic development. Regional Studies, 40(1), pp.55-73.

20. Miles, M.B., Huberman, A.M. and Saldana, J., 2013. Qualitative data analysis. Sage.

21. Mursitama, T.N., 2006. Creating relational rents: The effect of business groups on affiliated firms' performance in Indonesia. Asia Pacific Journal of Management, 23(4), pp.537-557.

22. Neubauer, H., 2003. The dynamics of succession in family businesses in western European countries. Family Business Review, 16(4), pp.269-281.

23. Nordqvist, M., Wennberg, K. and Hellerstedt, K., 2013. An entrepreneurial process perspective on succession in family firms. Small Business Economics, 40(4), pp.10871122.

24. Nugroho, Y., Putri, D.A. and Laksmi, S., 2012. Mapping the landscape of the media industry in contemporary Indonesia. Jakarta: Creative Common.

25. Panglaykim, J., 1984. Bisnis keluarga: perkembangan dan dampaknya (The Family Business: Development and Implication). Andi Offset.

26. Salvato, C., Chirico, F. and Sharma, P., 2010. Understanding exit from the founder's business in family firms. In Entrepreneurship and Family Business(pp. 31-85). Emerald Group Publishing Limited.

27. Sato, Y., 1993. The Salim group in Indonesia: the development and behavior of the largest conglomerate in Southeast Asia. The Developing Economies, 31(4), pp.408-441.

28. Sharma, P., 2004. An overview of the field of family business studies: Current status and directions for the future. Family business review, 17(1), pp.1-36.

29. Sharma, P., Chrisman, J.J. and Chua, J.H., 1997. Strategic management of the family business: Past research and future challenges. Family business review, 10(1), pp.1-35.

30. Stewart, A. and Hitt, M.A., 2012. Why can'ta family business be more like a nonfamily business? Modes of professionalization in family firms. Family Business Review, 25(1), pp.58-86.

31. Ward, J.L., 1997. Growing the family business: Special challenges and best practices. Family Business Review, 10(4), pp.323-337.

32. Yildirim-Öktem, Ö. and Üsdiken, B., 2010. Contingencies versus external pressure: professionalization in boards of firms affiliated to family business groups in late-industrializing countries. British Journal of Management, 21(1), pp.115-130.

33. Zellweger, T.M. and Astrachan, J.H., 2008. On the emotional value of owning a firm. Family Business Review, 21(4), pp.347-363. 